\title{
Development and characterization of two cell lines PDF and PDH from Puntius denisonii (Day 1865)
}

\author{
Wazir S. Lakra • M. Goswami • Kamalendra Yadav • \\ A. Gopalakrishnan • R. S. Patiyal • M. Singh
}

Received: 26 August 2010 / Accepted: 8 November 2010 / Published online: 7 December 2010 / Editor: J. Denry Sato

(C) The Society for In Vitro Biology 2010

\begin{abstract}
The Puntius denisonii colloquially and more popularly referred to as Miss Kerala is a subtropical fish belonging to the genus Puntius (Barb) and family Cyprinidae. Two cell lines PDF and PDH were developed from the caudal fin and heart of $P$. denisonii, respectively. The cell lines were optimally maintained at $26^{\circ} \mathrm{C}$ in Leibovitz- 15 medium supplemented with $10 \%$ fetal bovine serum. A diploid count of 50 chromosomes at passage 50 was observed in both the cell lines. The high growth potential of the cell lines was reflected from the cell doubling time of 28 and $30 \mathrm{~h}$ of PDF and PDH cell lines, respectively. The viability of the PDF and PDH cell lines was $70 \%$ and $76 \%$, respectively, after 4 mo of storage in liquid nitrogen $\left(-196^{\circ} \mathrm{C}\right)$. The origin of the cell lines was confirmed by the amplification of $653 \mathrm{bp}$ fragments of cytochrome oxidase subunit I of mitochondrial DNA genes.
\end{abstract}

Keywords Puntius denisonii $\cdot$ PDF $\cdot \mathrm{PDH} \cdot$ Cell line

\section{Introduction}

The Puntius denisonii colloquially and more popularly referred to as Miss Kerala is a subtropical fish endemic to Kerala of the Western Ghat Region (Mercy et al. 2007). The fish is characterized by a torpedo-shaped body with silver scales, a red line running from their snout, through the eye, back towards the middle of the body and below the red line, a black line that runs the length of the fish to the

W. S. Lakra $(\triangle) \cdot$ M. Goswami $\cdot$ K. Yadav $\cdot$ A. Gopalakrishnan R. S. Patiyal $\cdot$ M. Singh

National Bureau of Fish Genetic Resources,

Canal Ring Road Dilkusha Lucknow 226002, India

e-mail: wslakra@gmail.com tail. P. denisonii is a major export revenue earner fish in the ornamental fish export sector, with each of these beauties raking in at least US \$32. However, with no apparent steps from authorities concerned to curb the exports, the barb was slowly swimming towards becoming history. The International Union for Conservation of Nature has recently put $P$. denisonii on its Red List (Mathew 2010).

There have been several incidences of mass mortality of carps in culture systems suspected to be caused by microbial diseases, particularly of viral etiology (Roberts et al. 1993; Mohan and Shankar 1994). Hence, development of cell line from tropical fish species for identifying pathogenesis of viral diseases and for vaccine production against viral and bacterial diseases is imperative. Most of the cell lines have been developed from temperate fishes in the past (Fryer and Lannon 1994) except some recent reports on Tor putitora (Lakra et al. 2006a), Lates calcarifer (Lakra et al. 2006b; Parameswaran et al. 2006, 2007), Epinephelus coioides and Chanos chanos (Parameswaran et al. 2007), and Labeo rohita (Lakra et al. 2010).

The development of cell lines from $P$. denisonii, a highly valued ornamental cyprinid, would facilitate pathological studies and other fish diseases of carps. This paper reports two characterized cell lines PDF and PDH for the first time from the caudal fin and heart of $P$. denisonii, respectively.

\section{Materials and Methods}

Healthy juveniles of $P$. denisonii (body weight, 7 to $10 \mathrm{~g}$; body length, 5 to $10 \mathrm{~cm}$ ) were obtained from National Bureau of Fish Genetic Resources, Kochi Unit. Prior to sacrifice, the specimens were starved for a day and allowed to swim in well-aerated sterile water. The specimens were 
euthanized by keeping them on ice for 5-10 min and surface sterilized by dipping in an iodophore $(0.5 \% \mathrm{w} / \mathrm{v}$ iodine; Betadine, Pharmabutor, India) for $5 \mathrm{~min}$. Primary cell cultures were initiated by aseptically collecting caudal fin and heart tissues from the fish. The tissues were transferred to phosphate buffered saline (PBS; Invitrogen, Carlsbad, California (USA)), containing antibiotic and antimycotic solution (1,000 U penicillin, 1,000 $\mu \mathrm{g}$ streptomycin, and $25 \mu \mathrm{g}$ amphotericin $\mathrm{B} \mathrm{ml}^{-1}$; Invitrogen). The tissue samples were then minced with sterile dissecting blades and scissors at room temperature and washed four times with PBS containing antibiotic and antimycotic solution. Approximately 25 tissue fragments ( 1 to $2 \mathrm{~mm}^{3}$ ) were individually explanted into $25 \mathrm{~cm}^{2}$ tissue culture flasks (Nunc, Roskilde, Denmark) in $50 \mu \mathrm{l}$ of fetal bovine serum (FBS; Invitrogen). After allowing the tissue to attach for $6 \mathrm{~h}$ at room temperature, $5 \mathrm{ml}$ of Leibovitz-15 (L-15) medium containing $20 \%$ FBS was added to each flask.

The flasks were observed daily for attachment of explants, spreading and proliferation of cells, morphological details using an inverted microscope (Olympus Optical Co., Ltd., Tokyo, Japan). Upon reaching 95\% confluency, the cells were trypsinized using TPVG solution $(0.1 \%$ trypsin, $0.2 \%$ ethylenediaminetetraacetic acid, EDTA, and $2 \%$ glucose in $1 \times \mathrm{PBS})$. The subcultured cells were grown in fresh L-15 with $15 \%$ FBS. In the initial ten subcultures, $50 \%$ of the culture medium was replaced with the fresh medium. The concentration of FBS in the L-15 medium was reduced to $10 \%$ for further subculturing.

Growth characteristics of the cell lines in L-15 media were assessed at five different incubation temperatures $\left(18^{\circ} \mathrm{C}, 22^{\circ} \mathrm{C}\right.$, $26^{\circ} \mathrm{C}$, and $30^{\circ} \mathrm{C}$ ) for $7 \mathrm{~d}$. A seeding concentration of $1 \times$ $10^{5}$ cells $\mathrm{ml}^{-1}$ at passage 15 and subsequent passages was used in $25 \mathrm{~cm}^{2}$ tissue culture flasks. On alternate days, three flasks from different temperatures at which they were incubated were withdrawn, trypsinized, and cell counting performed (four counts per flask) using a hemocytometer. Analogous procedures were performed for the effects of various concentrations of FBS $(5 \%, 10 \%, 15 \%$, and $20 \%)$ on cell growth at $26^{\circ} \mathrm{C}$ for $7 \mathrm{~d}$.

Each dish (60-mm diameter; Terumo, Tokyo, Japan) was seeded with $5.0 \times 10^{6} \mathrm{PDF}$ and PDH cells in $5 \mathrm{ml}$ of the medium for estimating cell doubling time. The medium was renewed every third d. At the time of the first change of medium, a half of the volume was renewed. The number of the cells per dish was determined at various time points. Cell counts were made on triplicate plates with a hemocytometer. Cell doubling time was confirmed by 3-(4,5dimethylthiazol-2-yl)-2,5-diphenyl-tetrazdium bromide (MTT) assay (Hansen et al. 1989).

The ability of cells to survive in liquid nitrogen $\left(\mathrm{LN}_{2}\right)$ and their stability were assessed in three replicates in freezing medium at 20, 30, and 50 passages using previously described methods (Freshney 1994). Cells growing logarithmically for PDF and PDH were harvested and resuspended at densities of $3 \times 10^{6}$ to $4 \times 10^{6}$ cells ml $^{-1}$. The cell suspensions were carefully mixed with an equal volume of recovery medium (Invitrogen), as per the manufacturer's instruction. Aliquots $(1.0 \mathrm{ml})$ were dispensed into $1.5-\mathrm{ml}$ sterile cryovials (Nunc) held at $4^{\circ} \mathrm{C}$ for $2 \mathrm{~h},-20^{\circ} \mathrm{C}$ for $1 \mathrm{~h}$, at $-70^{\circ} \mathrm{C}$ overnight and then transferred into $\mathrm{LN}_{2}\left(-196^{\circ} \mathrm{C}\right)$. The frozen cells were recovered after 4 mo of post-storage by thawing at $37^{\circ} \mathrm{C}$ in a water bath. Following removal of the freezing medium by centrifugation, cells were suspended in L-15 with $10 \%$ FBS. The viability of cells was measured by trypan blue staining and the number of cells was counted using a hemocytometer. The viable cells were seeded into $25 \mathrm{~cm}^{2}$ tissue culture flasks for further subculturing.

Chromosomal counts were estimated for PDF and PDH cell lines at passage 50. Cells were seeded in duplicate $75 \mathrm{~cm}^{2}$ tissue culture flasks in L-15 medium with $10 \%$ FBS. After $24 \mathrm{~h}$ incubation, spent medium was replaced with $10 \mathrm{ml}$ of fresh medium containing $0.1 \mathrm{ml}$ colcemid solution $\left(1 \mu \mathrm{g} \mathrm{ml}^{-1}\right.$; Sigma, St Louis, MO) into the 1-d-old cell culture for $2 \mathrm{~h}$ at $28^{\circ} \mathrm{C}$. After harvesting by centrifugation $(70 \times g, 5 \mathrm{~min})$, the cells were suspended in a hypotonic solution consisting of $0.5 \% \mathrm{KCl}$ for $10 \mathrm{~min}$ and fixed in methanol/acetic acid $(3: 1)$. Slides were prepared following the conventional dropsplash technique (Freshney 1994). The chromosomes were counted under a microscope (Leica, Wetzlar, Germany), after staining with $5 \%$ Giemsa for $10 \mathrm{~min}$.

DNA extraction from PDF and PDH cells at passage 50 was accomplished following Ruzzante et al. (1996) with minor modifications. Briefly, samples were homogenized separately in incubation buffer $(10 \mathrm{mM}$ Tris- $\mathrm{HCl}$ and $10 \mathrm{mM}$ EDTA, $\mathrm{pH} 8.0$ ), centrifuged at $10,000 \mathrm{rpm}$ at $4^{\circ} \mathrm{C}$ after which the supernatants were digested with lysis buffer (10 mM Tris-HCl, 10 mM EDTA, $\mathrm{pH}$ 8.0, 0.5\% SDS, and $50 \mu \mathrm{g} / \mathrm{ml}$ proteinase $\mathrm{K}$ ). After incubation at $37^{\circ} \mathrm{C}$ for overnight the digests were deproteinized by successive phenol/chloroform and iso-amyl alcohol extraction and DNA was recovered by ethanol precipitation, drying, and resuspension in TE buffer. The concentration of isolated DNA was estimated at wavelength of $260 \mathrm{~nm}$ using a UV spectrophotometer. The DNA was diluted to get a final concentration of $100 \mathrm{ng} \mu \mathrm{l}^{-1}$.

The $653 \mathrm{bp}$ fragments of cytochrome oxidase subunit I (COI) was amplified in a final concentration of $50 \mu \mathrm{l}$ volume with a final concentration of $5 \mu \mathrm{l}$ of $10 \times \mathrm{Taq}$ polymerase buffer, $2 \mu \mathrm{l}$ of $\mathrm{MgCl}_{2}(50 \mathrm{mM}), 0.25 \mu \mathrm{l}$ of each dNTP $(0.05 \mathrm{mM}), 0.5 \mu \mathrm{l}$ of each primer $(0.01 \mathrm{mM}), 0.6 \mathrm{U}$ of Taq polymerase, and $5 \mu \mathrm{l}$ of genomic DNA. The primers used for the amplification of the COI gene were FISHF1-5' TCAACCAACCACAAAGACATTGGCAC $3^{\prime}$ and FISHR1-5'TAGACTTCTGGGTGGCCAAAGAATCA3' 

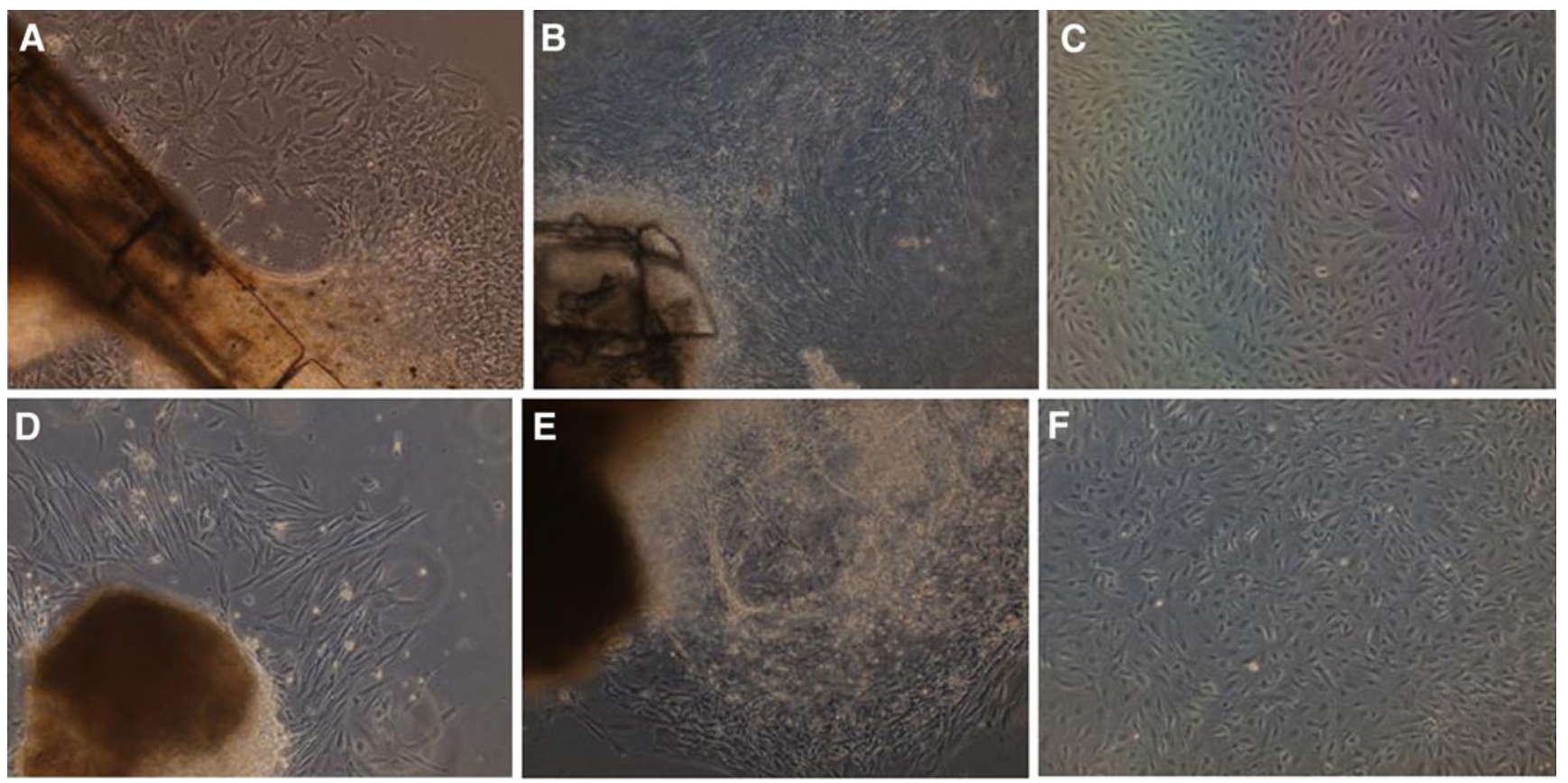

Figure 1. Phase contrast photomicrographs of PDF $(A-C)$ and PDH $(D-F) . A, D$ : Primary culture on day 5 following seeding tissue explant. $C, D$ : Confluent monolayer of the cells from the explant. $E, F$ : Subcultured cells at passage $30(100 \times)$.

(Ward et al. 2005). The thermal regime consisted of an initial step of $2 \mathrm{~min}$ at $95^{\circ} \mathrm{C}$ followed by 35 cycles of $40 \mathrm{~s}$ at $94^{\circ} \mathrm{C}, 40 \mathrm{~s}$ at $54^{\circ} \mathrm{C}$, and $1 \mathrm{~min} 10 \mathrm{~s}$ at $72^{\circ} \mathrm{C}$ followed by final extension of $10 \mathrm{~min}$ at $72^{\circ} \mathrm{C}$.

A.



C.

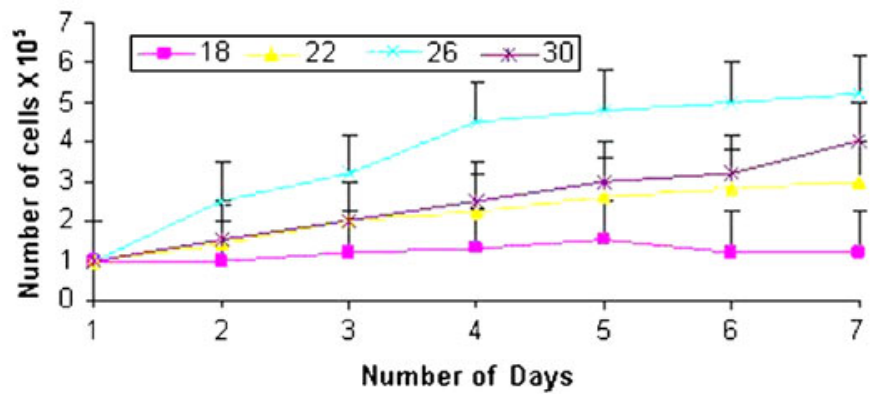

The PCR products were visualized on $1.2 \%$ agarose gels, and the most intense products were selected for sequencing. Products were labeled using the BigDye Terminator V.3.1 Cycle sequencing Kit (Applied Biosystems, Inc., Foster

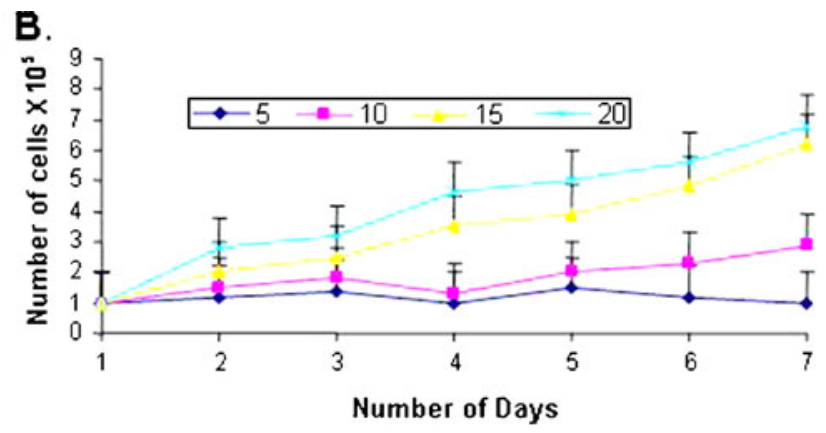

D.

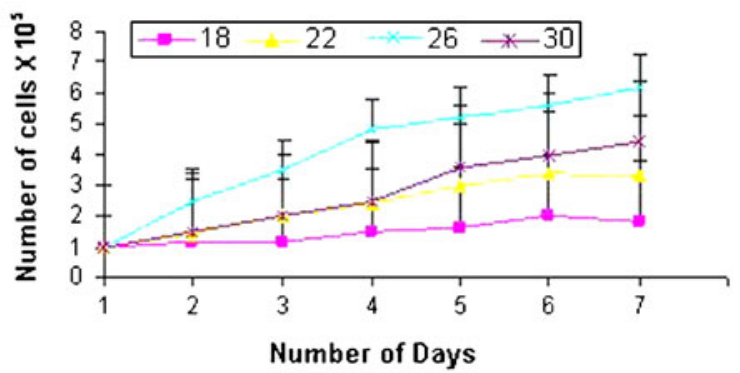

Figure 2. Growth of cells at different concentrations of FBS (percentage), $A, \mathrm{PDF}$ and $B, \mathrm{PDH}$. Growth of cells at different temperatures $\left({ }^{\circ} \mathrm{C}\right)$, $C, \mathrm{PDF}$ and $D, \mathrm{PDH}$. 
City, California) and sequenced bidirectionally using an ABI 3730 capillary sequencer following manufacturer's instructions. The obtained sequences of PCR fragments were compared to the known sequences of the species.

Data were expressed as mean \pm SE. The number of cells was analyzed with independent samples test, and statistical analysis was carried out using SPSS software. A value of $P<$ 0.05 was considered as significant.

\section{Results and Discussion}

In vitro cell culture system from caudal fin (PDF) and heart (PDH) of $P$. denisonii was established by means of the explant technique. Morphologically, PDF and PDH comprised of fibroblast-like cells during subsequent passages (Fig. 1). Initially, fibroblastic and epithelial cells were found in both the cell lines, but after several subcultures, fibroblastlike cells predominated in both the cell lines. Usually, a predomination of fibroblastic cells over epithelioid cells in cell cultures from fish has been reported (Bejar et al. 1997; Lai et al. 2003; Lakra et al. 2006a). Ye et al. (2006) developed a fibroblast-like cell line (LJH-2) from Lateolabrax japonicus. In contrast, sea perch heart cells migrating from heart tissue have been reported to be epithelioid in morphology with no change during successive propagation (Tong et al. 1998).

Radiation of cells from the explants started after 4-5 d in $25 \mathrm{~cm}^{2}$ tissue culture flasks for PDF and PDH cell lines. A confluent monolayer of the cells from the explant was observed in 7 to $10 \mathrm{~d}$. The confluent monolayer was achieved at a split ratio of 1:2. The cells adhered well to the substratum and achieved subsequent confluency in 5$7 \mathrm{~d}$ at $26^{\circ} \mathrm{C}$ in L-15 medium containing $15 \%$ FBS during subsequent subcultures. The PDF and PDH cell lines were subcultured 60 and 55 times, respectively. During the initial ten subcultures at 5-7 d intervals, a combination of $50 \%$ each of new and old medium was used. In subsequent subcultures, cells were subcultured in L-15 with $10 \%$ FBS in a ratio of $1: 3$ at $2-3 \mathrm{~d}$ of interval. Both the cell lines were grown in L-15 medium supplemented with $10 \%$ FBS.

The growth rate of the cells in medium containing $20 \%$ FBS was higher than that of cells in medium containing $5-15 \%$ FBS (Fig. $2 a, b$ ). The growth rate of the present cells increased as the FBS concentration increased from $5 \%$ to $20 \%$. However, a $10-15 \%$ concentration of FBS also provided relatively good growth and this is an advantage to maintain the cell line using $10 \%$ FBS at low cost. Relatively good growth of the fish were observed at $10 \%$ FBS, but maximum growth was observed with the concentrations of $15 \%$ and $20 \%$ (Hameed et al. 2006; Lakra et al. 2006b and Ye et al. 2006). The cells of the PDF and PDH cell lines were able to grow at temperatures between $26^{\circ} \mathrm{C}$ and $30^{\circ} \mathrm{C}$. However, maximum growth was obtained at $26^{\circ} \mathrm{C}$ for PDF and PDH cell lines (Fig. $2 c, d$ ), which was in conformity with other fish cell lines reported earlier (Tong et al. 1997; Lakra et al. 2006a). No significant growth was observed at $18^{\circ} \mathrm{C}$ and $22^{\circ} \mathrm{C}$ in the cell lines. One of the advantages of cell lines that grow over a wide temperature range is their potential suitability for isolating both warm water and coldwater fish viruses (Nicholson et al. 1987).

The growth potential of PDF and PDH cell line was assessed by MTT assay that revealed fast growth potential of PDF and PDH cell lines with a cell doubling time of 28 and $30 \mathrm{~h}$ for PDF and PDH cell lines at 50th passage. The cell doubling time reported in the continuous cell line SAF-1 from Sparus aurata, RTG-2 cell line, PSM-1cell line from a hybrid between Xiphophorus maculatus and Xiphophorus hellen was $48 \mathrm{~h}$ (Plumb and Wolf 1971; Wakamatsu 1981; Bejar et
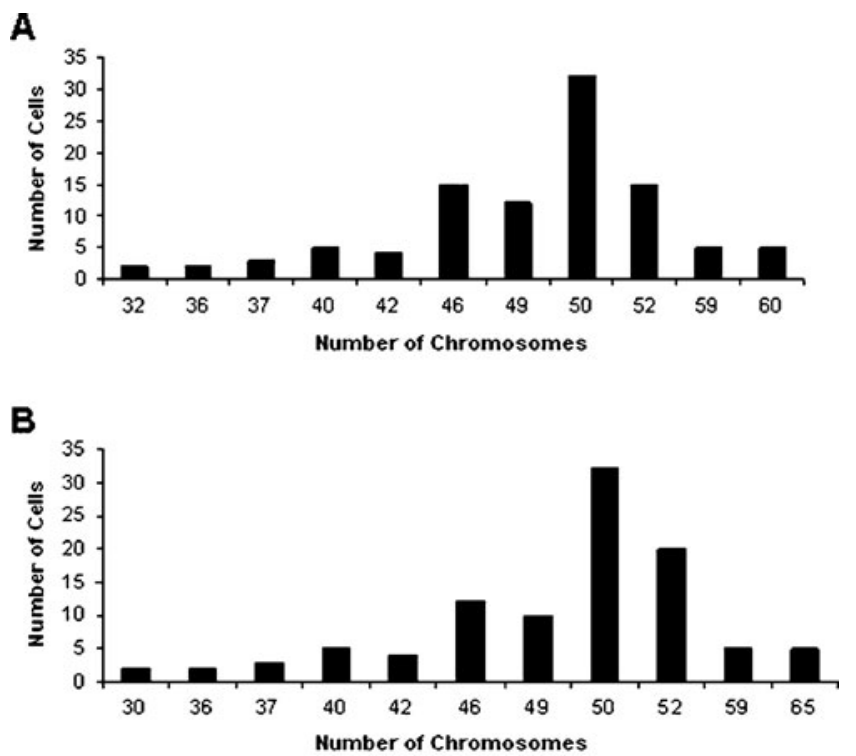

C

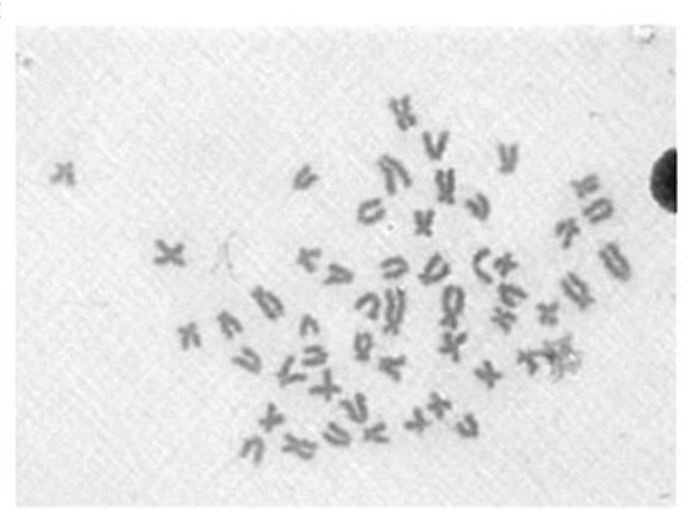

Figure 3. Chromosome number distribution at 50 passages of $(A)$ PDF cell line $(B)$ PDH Cell Line $(C)$. A standard chromosome spread of $P$. denisonii. 
al. 1997). TP-1 cell line developed from T. putitora showed population doubling time as $28 \mathrm{~h}$ (Lakra et al. 2006a). Hameed et al. 2006 reported population doubling time of $36 \mathrm{~h}$ in a continuous cell line (SISK) from sea bass (L. calcarifer).

Evaluation of the viability of the cells stored in liquid nitrogen $\left(-196^{\circ} \mathrm{C}\right)$ established the capability of cells to survive following 4 mo of storage. Seventy percent of PDF cells and $76 \%$ of $\mathrm{PDH}$ cells from each vial remained viable after the storage period and retained the ability to attach and grow at $26^{\circ} \mathrm{C}$. Following storage, no obvious alterations in morphology or growth pattern were observed for cells. The feasibility of cryopreservation of the present cell lines was demonstrated where the recovery rate of the cells after 6 mo of cryopreservation was $70 \%$ and $76 \%$ for PDF and PDH cell lines, respectively, after 4 mo of storage in liquid nitrogen $\left(-196^{\circ} \mathrm{C}\right)$. It was 50\% for SAF-1 (gilt-head sea bream) (Bejar et al. 1997), 73\% for GF-1 (grouper; Chi et al. 1999), and 80-85\% for SF (Asian seabass; Chang et al. 2001).

The results of chromosome counts of 110 metaphase plates of PDF and PDH cell lines at passage 50 revealed that the number of diploid chromosomes in the cells ranged from 32 to 60 and 30 to 65 , respectively, with a modal peak at 50 chromosomes (Fig. $3 a, b$ ). A standard chromosome spread of $P$. denisonii is shown in Fig. $3 c$. The modal chromosome number $(2 n=50)$ of PDF and PDH cells is identical to the modal chromosome number, reported earlier (NBFGR 1998).

The capacity to authenticate a cell line is very useful to check the originality and cross contamination with other cell line. Species identification of cell lines is crucial for scientific research accuracy and reproducibility. Analysis of mitochondrial COI was performed to verify the origin of the cell line. Amplification from the COI genes for both the cell lines revealed the expected PCR products of $653 \mathrm{bp}$. GenBank accession number of COI gene of PDF and PDH cell lines were HQ176002 and HQ176003, respectively. The sequence analysis of COI fragments showed 100\% similarity with respective gene fragment of $P$. denisonii voucher specimens (GenBank Accession no. GQ247553). The results indicated that the cell lines were of $P$. denisonii. Hebert et al. (2003) have demonstrated the utility of COI gene as a universal barcode, referred as "DNA barcoding" for the genetic identification of animal life. Recently, Cooper et al. (2007) used COI region for identification of 67 cell lines used for barcode analysis. Our analysis also proves the utility of COI gene in the identification of the cell lines from $P$. denisonii.

Acknowledgments The authors thank Dr. S. Ayyappan, Director General, Indian Council of Agricultural Research, for his support and encouragement for the research program. The authors also thank Dr. V. S. Basheer of NBFGR, Kochi Unit, for his help in collecting the fish samples.

\section{References}

Bejar J.; Borrego J. J.; Alvarez M. C. A continuous cell line from the cultured marine fish gilt-head seabream (Sparus aurata L.). Aquaculture 150: 143-153; 1997.

Chang S. F.; Ngoh G. H.; Kueh L. F. S.; Qin Q. W.; Chen C. L.; Lam T. J.; Sin Y. M. Development of a tropical marine fish cell line from Asian seabass (Lates calcarifer) for virus isolation. Aquaculture 192: 133-145; 2001.

Chi S. C.; Hu W. W.; Lo B. J. Establishment and characterization of a continuous cell line (GF-1) derived from grouper, Epinephelus coioides (Hamilton): a cell line susceptible to grouper nervous necrosis virus (GNNV). J Fish Dis 22: 173-182; 1999.

Cooper J. K.; Sykes G.; King S. Species identification in cell culture: a two-pronged molecular approach. In vitro Cell Dev Biol 43: 344-351; 2007.

Freshney R. I. Culture of animal cells: a manual of basic technique. Wiley-Liss, New York; 1994.

Fryer J. L.; Lannon C. N. Three decades of fish cell culture: a current listing of cell lines derived from fish. J Tissue Cult Methods 16: 87-94; 1994.

Hameed A. S. H.; Parameswaran V.; Shukla R.; Singh I. S. B.; Thirunavukkarasu; Bhonde R. R. Establishment and characterization of India's first marine fish cell line (SISK) from the kidney of sea bass (Lates calcarifer). Aquaculture 257: 92-103; 2006.

Hansen M. B.; Nielsen S. E.; Berg K. Re-examination and further development of a precise and rapid dye method for measuring cell growth/cell kill. J Immunol Methods 119: 203-210; 1989.

Hebert P. D. N.; Cywinska A.; Ball S. L.; Waard J. R. D. Biological identifications through DNA barcodes. Proceedings of Royal Society of London. B 270: 313-321; 2003.

Lai Y. S.; John J. A. C.; Lin C. H.; Guo I. C.; Chen S. C.; Fang K.; Lin C. H.; Chang C. Y. Establishment of cell lines from a tropical grouper, Epinephelus awora (temminck \& schelegel), and their susceptibility to grouper irido- and nodaviruses. J Fish Dis 26: 31-42; 2003.

Lakra W. S.; Bhonde R. R.; Sivakumar N.; Ayyappan S. A new fibroblast like cell line from the fry of golden masher Tor putitora (Ham). Aquaculture 253: 238-243; 2006a.

Lakra W. S.; Sivakumar N.; Goswami M.; Bhonde R. R. Development of two cell culture systems from Asian seabass Lates calcarifer (Bloch). Aquaculture Res 37: 18-24; $2006 \mathrm{~b}$.

Lakra W. S.; Swaminathan T. R.; Rathore G.; Goswami M.; Yadav K.; Kapoor S. Development of three new diploid cell lines from Labeo rohita. Biotechnol Prog 26(4): 1008-1013; 2010.

Mathew D. M. 'Miss Kerala' finds spot on IUCN Red List. The Hindu, 31 January 2010; 2010.

Mercy T. V. A.; Goapalakrishnan A.; Kapoor D.; Lakra W. S. Ornamental fishes of the Western Ghats of India. NBFGR, Lucknow, p 70; 2007.

Mohan C. V.; Shankar K. M. Role of fungus in epizootic ulcerative syndrome of fresh and brackishwater fishes of Karnataka, India. Current Science 66: 656-658; 1994.

NBFGR, Fish chromosome atlas. National Bureau of Fish Genetic Resources Special Publication, No. 1. Lucknow, India, pp 332; 1998.

Nicholson B. L.; Danner D. J.; Wu J. L. Three new continuous cell lines from marine fishes of Asia. In vitro Cell Dev Biol 23: 199 $204 ; 1987$.

Parameswaran V.; Ahmed V. P. I.; Shukla R.; Bhonde R. R.; Hameed A. S. S. Development and characterization of two new cell lines from milkfish (Chanos chanos) and grouper (Epinephelus coioides) for virus isolation. Mar Biotech 9: 281291; 2007.

Parameswaran V.; Shukla R.; Bhonde R. R.; Hameed A. S. S. Splenic cell line from sea bass, Lates calcerifer: establishment and characterization. Aquaculture 261: 43-53; 2006. 
Plumb J. A.; Wolf K. Fish cell growth rates: quantitative comparison of RTG-2 cell growth at 5-25 ${ }^{\circ}$. In Vitro Cell Dev Biol Plant 7 (1): 1054-5476; 1971.

Roberts R. J.; Willoughby L. G.; Chinabut S. Mycotic aspect of epizootic ulcerative syndrome (EUS) of Asian fishes. $J$ Fish Dis 16: 169-183; 1993.

Ruzzante D. E.; Taggart C. T.; Cook C.; Goddard S. Genetic differentiation between inshore and offshore Atlantic cod (Gadus morhua) off Newfoundland: microsatellite DNA variation and antifreeze level. Can J Fish Aquat Sci 53: 634-645; 1996.

Tong S. L.; Lee H.; Miao H. Z. The establishment and partial characterization of a continuous fish cell line FG- 9307 from the gill of flounder. Paralichthys olivaceus. Aquaculture 156: 327-333; 1997.
Tong S. L.; Miao H. Z.; Li H. Three new continous fish cell lines of SPH, SPS, and RSBF derived from sea perch (Lateolabrax japonicus) and red sea bream (Pagrosomus major). Aquaculture 169: 143-151; 1998.

Wakamatsu Y. Establishment of a melanoma cell line from the platyfish-swordtail hybrid. Cancer Res 41: 679-680; 1981.

Ward R. D.; Zemlak T. S.; Innes B. H.; Last P. R.; Hebert P. D. N. DNA barcoding Australia's fish species. Philos Trans $R$ Soc Lond, Ser B 360: 1847-1857; 2005.

Ye H. Q.; Chen S. L.; Sha Z. X.; Xu M. Y. Development and characterization of cell lines from heart, liver, spleen and head kidney of sea perch Lateolabrax japonicus. J Fish Biol 69: 115126; 2006. 